DOI 10.37882/2223-2982.2020.06.14

\title{
СПОСОБЫ ВЫРАЖЕНИЯ КАТЕГОРИИ ДЕРОГАТИВНОСТИ В РАЗНОСИСТЕМНЫХ ЯЗЫКАХ (НА МАТЕРИАЛЕ РУССКОГО, АНГЛИЙСКОГО И ТАТАРСКОГО ЯЗЫКОВ)
}

\section{THE WAYS OF EXPRESSING \\ THE CATEGORY OF DEROGATIVITY \\ IN DIFFERENT LANGUAGES \\ (BASED ON THE RUSSIAN, ENGLISH AND TATAR LANGUAGES)}

\section{Kurbanov Yu. Kabirova}

Summary: The article is devoted to the analysis of the linguistic units with strongly expressed pejorative evaluation. The object of the study is the language units of the category of derogativity realization in the English, Russian and Tatar languages. In the course of the research the authors analyzed the main linguistic means of expressing the category of derogativity and the features of their functioning in the literary texts of the languages under study.

Keywords: derogativity, category of derogativity, assessment, negative connotation, linguistic level.

\author{
Курбанов Ибрагим Алиевич \\ К.филол.н., профессор, Сургутский государственный \\ университет \\ ibragimkurbanov@mail.ru \\ Кабирова Юлия Ильнуровна \\ Сургутский государственный университет \\ cabirova.julia@bk.ru
}

Аннотация: Данная статья посвящена проблеме исследования языковых единиц с ярко выраженной уничижительной оценочностью. Объектом исследования являются языковые средства реализации понятийной категории дерогативности в английском, русском и татарском языках. В ходе работы авторами были проанализированы основные языковые средства выражения категории дерогативности и особенности их функционирования в художественных текстах исследуемых языков.

Ключевые слова: дерогативность, категория дерогативности, оценка, отрицательная коннотация, языковой уровень.
$\mathrm{H}$ астоящая статья посвящена одной из актуальных и мало разработанных проблем - исследованию понятийной категории дерогативности.

Дерогативы - это слова негативной оценки со значением пренебрежительности, презрительности, уничижительности, преуменьшения, которые также служат средством маркирования стиля речи, средством экспрессивного усиления, выраженного в тексте.

Существует множество способов передачи дерогативного значения. Их реализация зависит не только от строя языка (агглютинативный, флективный, аналитический), но и от имеющихся продуктивных моделей словообразования, от структуры, семантики и частеречной принадлежности основ.

Категория дерогативности, традиционно находящая свое выражение на уровне морфологии в синтетических языках, к каковым относится русский язык, в агглютинативном - татарском языке, в аналитическом по своей фактуре английском языке, тоже должна быть как-то представлена [12]. Так как арсенал уничижительных аффиксов в татарском языке не велик, и лишь некоторые из них являются продуктивными аффиксами, оказыва- ется необходимым выяснить, каким образом категория дерогативности, которая передает значение пренебрежительности, презрительности, уничижительности, отражается на морфолого-словообразовательном, лексико-семантическом и фразеологическом уровнях языка.

Цель настоящей статьи - выявить и сопоставить основные языковые средства выражения категории дерогативности в английском, русском и татарском языках и особенности их функционирования в художественных текстах.

Начнем с морфолого-словообразовательного уровня. Русский язык, имеющий большое количество морфолого-деривационных средств, несомненно, богат суффиксами, которые могут выражать отрицательную коннотацию - презрение, иронию, уничижительность, пренебрежение.

Наиболее распространенными из них являются сле-

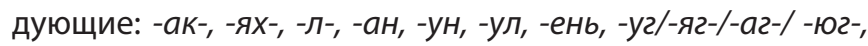
-шин-, -ин, -нича-/-ича-, -ствова-, -ищ-, -ущ-, -ющ, -аст-, -ист. Они встречаются в таких словах, как, например, nuсака, растеряха, подпевала, интриган, драчун, грязнуля, дурень, журналюга, литературшина, домина, умничать, 
юродствовать, сборище, жаднущий, носастый.

В дополнении к ним мы можем выделить немало уменьшительных суффиксов, которые способны выразить пренебрежительное или презрительное отношение к предмету внимания или обсуждения: -очек-, -ишк/, -юшк-l, -ашк-, -онк, -енк(a), -ица, -очка, -ушка, -ок, -ек, -ец, -ико, -ецо, ечк(о),-це, -ице и так далее. Данные суффиксы можно встретить в следующих словах: дружочек, танцоришка, актеришка, бумажонка, лошаденка, президентишка, личико, Алексашки (о роде Долгоруких), книжича, избенка, сельцо, комнатенка, растеньице, комнатушка, капиталец, аристократишка, дельце, письмецо.

Рассмотрим примеры из художественной литературы.

1. Старуха закрыла глаза и слегка завалилась на бок [9].

В данном примере мы наблюдаем дерогатив «старуха», который образован с помощью словообразовательного аффикса «-ух». Согласно «Словарю словообразовательных аффиксов современного русского языка» В. В. Лопатина и И. С. Улуханова, суффикс «-ух» имеет следующее значение: «1. лицо, характеризующееся признаком, названным мотивирующим словом. 2. В стилистически сниженных (разг. или прост., в именах и названиях лиц фамильярных) синонимах мотивирующих существительных» [11].

В вышеприведенном примере мы видим, что данная словообразовательная единица образует стилистически сниженный синоним мотивирующего имени существительного, а также имеет функцию выражения пренебрежения.

2. За всеми манипуляциями советского служащего застенчиво следили двое молодых людей - мужчина и девuиa [9].

В данном примере лексическая единица, обладающая дерогативным окрасом, образована с помощью суффикса «-ица». Согласно «Новому толково-словообразовательному словарю» Ефремовой, суффикс «-иц» имеет следующее одно из значений: «Формообразовательная единица, образующая имена существительные женского рода с уменьшительно-ласкательным, только с уменьшительным или только с ласкательным значением (вещица, землица, косица, лужица, сестрица и т.п.)» [1].

Таким образом, в данном примере мы наблюдаем, что к уменьшительному значению лексической единицы добавляется эмоциональное значение уничижительности, пренебрежительности.

К наиболее продуктивным дерогативным суффиксам в английском языке можно отнести: -let, ling, -y, -ie, -eer, -aster, -ard/-art, -ster, -о и его варианты -eroo/-aroo/-roo/oo, -ish. Например, Chicklet (цыпочка), kinglet (царек), таnlig (человечек), shorty (коротыш), pamphleteer (писака), oldster (старикашка), bazoo (брехня), wimpish.

Рассмотрим некоторые примеры из художественной литературы.

3. I was glad to notice that they had sufficient decency left in them to look very foolish [8].

Лексическая единица «foolish», которая переводится на русский язык, как «глупый», согласно «Кембриджскому англо-русскому словарю», образована путем добавления суффикса «-ish» к существительному «fool» - «дурак, глупец» [10].

При добавлении суффикса «-ish» к именным основам, одним из значений которого является обозначение сходства людей или предметов согласно толковому словарю английского языка «Collins English Dictionary», образуются прилагательные с дерогативной оценкой [7].

\section{Go on, get off a me, ya crumby bastard [8].}

В вышеприведенном примере использован дерогатив «crumby», переводящийся на русский язык, как «1) рассыпчатый, рыхлый 2) а) жалкий, убогий б) никудышный, бесполезный, никчемный», согласно «Кембриджскому англо-русскому словарю» [10].

Данная лексема образована путем добавления словообразовательного суффикса «-у», который добавляется к существительным для образования имен прилагательных, обладающими признаками и характеристиками мотивирующего существительного, согласно толковому словарю английского языка «Collins English Dictionary» [7].

Более того, данный пример обладает усиленной дерогативной окраской благодаря употреблению словосочетания, в котором существительное «bastard» (русс. - «скотина, ублюдок» [10]) и прилагательное «сrumby» функционируют в предложении для выражения презрения.

В татарском языке количество дерогативных суффиксов не так велико. Приведем некоторые примеры. Уменьшительно-ласкательный суффикс «-чык» часто может выражать пренебрежительное отношение, например, кuтап (книга) - китапчык (книжонка), бала (мальчик) - балачык (мальчонка).

Аффикс «-лы/ле» иногда выражает презрение к определенным отрицательным качествам индивида или его внешности: колак (уши) - колаклы (ушастый), кер (грязь) 
- керлы (грязный), икейөзлы (двуличный).

Присоединение аффикса «-сыз» к нейтральному слову дает дерогативное наименование, например, акыл (ум) - акылсыз (безмозглый), оят (совесть) - оятсыз (бессовестный), ямь (красота) - ямьсыз (некрасивый). Рассмотрим пример функционирования данного аффикса в художественной литературе.

\section{5. Рәхмәтсез балалар (русс. Неблагодарные дети) [13].}

Аффикс «-сыз» при добавлении к существительному с последним слогом переднего ряда образует прилагательные, наречия со значением «лишенный чего-либо, не обладающий чем-либо». В данном предложении дерогатив «рәхмәтсез» обладает функцией выражения пренебрежения.

6. Кортдай сикереп торды, шундук бөтен йокысы ачылды (Он вскочил как червь, и весь сон пропал) [13].

При добавлении суффикса «-дай» к существительному с последним слогом заднего ряда, оканчивающимся на все буквы, кроме глухих согласных, образует наречия со значением подобия. В качестве предмета для сравнения автор использует зооморфизм «корт» (русс. - червяк). Согласно «Татарско-русскому словарю» данная лексема имеет следующее значение: «червь, личинка; перен. тунеядеи, дармоед, паразит; перен. чувство, червь (сомнения, беспокойства)» [6]. Таким образом, мы можем пронаблюдать, что используемые для сравнения зооморфизм несет в себе добавочную негативную коннотацию в своем значении, что усиливает функцию дерогатива.

В результате исследования морфологических средств, которые выражают значение уничижительности в русском, английском и татарском языках, было выявлено наличие дерогативных суффиксов во всех трех языках. Перейдем к лексическому уровню языка.

Помимо аффиксации одними из основных средств передачи дерогативной оценки являются лексико-семантические средства. Они занимают одно из центральных мест в системе эмотивных средств языка. Данный факт может быть объяснён способностью лексических единиц языка передавать тончайшие стилистические и смысловые оттенки информации.

Перейдем к описанию лексико-семантических средств выражения категории дерогативности в художественной литературе. Рассмотрим примеры на русском языке.

7. Англичане ж сволочи, - ответил Ипполит Матвеевич. - Так им и надо. Они всегда Россию продавали [9].
В вышеприведенном примере автор использует дерогатив «сволочь», который, согласно «Толковому словарю русского языка» С. И. Ожегова, имеет следующее значение: «1. Негодяй, мерзавец. 2. Собир. сброд, подлые люди» [5]. [9].

\section{8. Я 6 такому дураку даже конюшни не дал строить}

В данном предложении используется дерогатив «дурак», имеющий следующее значение: «(разг.). 1. Глупый человек, глупец», согласно «Толковому словарю русского языка» С. И. Ожегова [5]. Более того, негативная коннотация усиливается благодаря тому, что употребляется указательное местоимение «такому».

9. Гимназист Савицкий, известный в гимназических кругах сорвиголова, радостно плюнул в вазон с фикусом [9].

Лексическая единица с дерогативным значением «сорвиголова» толкуется в «Фразеологическом словаре русского литературного языка» А.И. Федорова следующим образом: «разг. экспрес. Сумасбродный, взбалмошный человек» [14].

\section{Рассмотрим примеры английского языка.}

\section{Pencey was full of crooks [8].}

В вышеприведенном предложении используется существительное, обладающее дерогативным значением. Лексическая единица «crook», согласно «Кембриджскому англо-русскому словарю», означает «мошенник, жулик» [10].

11. The one ugly one, Laverne, wasn't too bad a dancer, but the other one, old Marty, was murder [8].

В данном примере используется дерогативная единица «иgly», которая в русском языке имеет следующее значение: «Уродливый, неприятный, противный» [10]. Более того, мы наблюдаем замену существительного местоимением «опе», что несет в себе оттенок фамильярности, усиливая негативный эффект и отрицательную оценку персонажа.

Проанализируем вторую часть предложения. Эмоционально-экспрессивный смысл передается здесь благодаря нескольким компонентам. Знакомство читателей с девушкой начинается с эпитета «old», далее герой сообщает о том, что танцевала она «убийственно». Слово «murder» («убийство» [10]) - в данном контексте употреблено в переносном смысле, однако приобретает здесь особое дерогативное значение с функцией выражения пренебрежения. 


\section{He was a real moron [8].}

Дерогатив, употребленный в данном предложении, имеет следующее значение: «moron - идиот, болван», согласно «Кембриджскому англо-русскому словарю» [10].

Перейдем к анализу примеров татарского языка.

13. - юләр сорау, - дигән Хужса, - билгеле, крестьян. (Русс. - Дурацкий вопрос, - сказал Хозяин, - конечно, крестьянин) [13].

В данном примере использовано прилагательное «юләр», имеющее дерогативую коннотацию. Обратимся к «Татарско-русскому словарю». «Юләр - 1. Сущ. дурак, дурачок, глупый 2. Пр. глупый, ненормальный. 3. Сущ. и пр. умалишённый, душевнобольной». Дерогативная лексема выступает в предложении с функцией выражения пренебрежения [6].

14. Ул үзенен азгынлыгы белән билгеле. (Русс. - Он известен своей распущенностью) [13].

Негативная коннотация, а именно эмоциональнопренебрежительный компонент в данном предложении достигается благодаря использованию лексической единицы «азгынлык», имеющей следующий перевод на русский язык: «1. избалованность, безнравственность, разнузданность, распущенность, беспутность 2. развратность, развращённость, распутность, блудливость, похотливость» [6].

15. Гомере буе сантый булып яшәп булмый инде. (Русс. - Нельзя прожить всю жизнь дуралеем) [13].

В вышеприведенном примере использовано существительное с дерогативным значением «сантый» (русс. - дурачок, дуралей) [6].

Таким образом, мы можем сделать вывод, что лексико-семантические средства выражения категории дерогативности представлены во всех трех исследуемых языках. Подобные лексемы обычно однозначны; оценка, которая содержится в их значении, выражена настолько определенно, что мы не можем употребить их в других значениях.

Одним из самых важных средств выражения отрицательной субъективной оценки личности в русском, английском и татарском языках являются фразеологические единицы, выражающие оценку посредством сравнения. Выражается субъективная оценка личности посредством ее сравнения с какими-либо представителями фауны, абстрактными понятиями или неодушевленными предметами.

\section{Рассмотрим некоторые примеры.}

16. А теперь он, как иыпленок попался на лучшем своем коммерческом предприятии, от которого ждал больших барышей и обеспеченной старости [9].

В данном примере мы наблюдаем сравнение Варфоломея Коробейникова с цыпленоком. Образ цыпленка в русской литературе традиционно символизирует детей, а данное сравнение в предложении носит функцию насмешки над персонажем и его поступками.

Рассмотрим пример на английском языке.

17. She was about as kindhearted as a goddam wolf. (Волчица и та, наверно, добрее.)[8].

В данном предложении приведен пример сравнения персонажа с волчицей. В английских сказках волк олицетворяет злое начало, так же, как и в русских народных сказках. Таким образом, четко прослеживается дерогативное значение сравнения, несущее в себе функцию уничижения.

В татарском языке часто встречаются метафорические сравнения, используемые для переноса каких-либо качеств животных на человека и с целью создания оценочной негативной коннотации.

\section{8. Куян кебек куркак. (Трусливый, как заяи) [13].}

В народном творчестве татарского языка образ зайца связан со значением трусливости, ролью жертвы и беззащитного животного. Так, согласно «Большому татарско-русскому словарю» [6], лексическая единица «куян» имеет следующее значение: «перен. трус, заяц». В русском же языке имеется большое количество поговорок и пословиц, способных отразить данную черту животного: «Пуганый заяц и куста боится», «Вор, что и заяц: и тени своей боится», «дрожать как заяц» и т.д.

Таким образом, сравнение, представляющее собой сопоставление двух предметов, имеющее какой-либо общий для них признак, в целях более яркой и наглядной характеристики одного из них, является еще одним средством передач дерогативного значения во всех трех исследуемых языках.

Дерогативная лексика является одним из средств передачи выразительности и, следовательно, избыточного смысла, который зачастую подменяет буквальный смысл фразы. Суть употребления дерогативной лексики сводится к тому, что автор выражает уничижительную оценку не впрямую, а посредством довольно ограниченного набора легко узнаваемых морфолого-словообразовательных, лексико-семантических и фразеологических средств. 
Русский язык, синтетический по своему характеру, богат морфолого-словообразовательными средствами выражения категории дерогативности. Анализ морфолого-словообразовательных способов реализации уничижительной оценки в английском и татарском языках показал, что в данных языках характерные для русского языка дерогативные аффиксы представлены слабо, а потому недостаточное число лексем с дерогативными аффиксами компенсируют лексико-семантический и фра- зеологический уровни.

Результаты исследования показывают, что категориальное значение дерогативности может относиться как целиком к лексической единице, так и к различным ее компонентам: к одному из значений многозначного слова, к иллюстративному примеру или фразеологическому сочетанию с данным словом, или к нескольким компонентам одновременно.

\section{ЛИТЕРАТУРА}

1. Ефремова Т. Ф. Новый словарь русского языка. Толково-образовательный. - М.: Рус. яз. 2000. - в 2 т. - 1209 с.

2. Кабирова Ю.И., Курбанов И.А. Зооморфная метафора как способ выражения категории дерогативности в разносистемных языках. Лингвокультурология: ежегодный сборник научных трудов / Уральский государственный педагогический университет. - Екатеринбург:, 2019. - Выпуск 13. - 234 с.

3. Курбанов И.А., Кабирова Ю.И. Морфологические средства выражения дерогативности в русском, английском и татарском языках. Молодой исследователь: вызовы и перспективы. Сборник статей по материалам LCIX международной научно-практической конференции. - Москва, 2018. - С. 21-24.

4. Михельсон М.И. // Большой толково-фразеологический словарь Михельсона. - ETS Publishing house, 2004. - 2208 c.

5. Ожегов С.И. // Толковый словарь русского языка. - 28-е изд., перераб. - М.: Мир и Образование: ОНИКС, 2012. - 1375 с.

6. Татарско-русский словарь: В 2-х т. - Казань : Магариф, 2007. - 726 с.

7. Collins English Dictionary / Режим доступа: https://www.collinsdictionary.com

8. Salinger J. D. The catcher in the rye. Электронная книга $-273 \mathrm{c}$.

9. Ильф И., Е. Петров. Двенадцать стульев. Электронная книга. -379 с.

10. Кембриджский англо-русский словарь / Режим доступа: https://dictionary.cambridge.org/

11. Лопатин. В.В., И.С. Улуханов. Словарь словообразовательных аффиксов современного русского языка. - М.: Издательский центр «Азбуковник», 2016. 812 c. Электронная версия словаря / Режим доступа: http://www.ruslang.ru/doc/lopatin-uluxanov.pdf

12. Рамазанова А.Х. Категория дерогативности в разносистемных языках: семантика и функционирование / Режим доступа: http://www.dissercat.com/ content/kategoriya-derogativnosti-v-raznosistemnykh-yazykakh-semantika-i-funktsionirovanie

13. Татарская народная библиотека / Режим доступа: http://kitap.net.ru

14. Федоров А.И. Фразеологический словарь русского литературного языка / Режим доступа: https://gufo.me/dict/fedorov 